\title{
MATERIAL RESOURCES EFFICIENCY EVALUATION METHOD FOR MANUFACTURING SYSTEMS WITH GENERALIZED STRUCTURE
}

\author{
K.S. Khaldin, lar3811@yandex.ru \\ South Ural State University, Chelyabinsk, Russian Federation
}

\begin{abstract}
This paper describes a new approach to material resources efficiency evaluation for industrial enterprises. This approach is based on material flow cost accounting and is aimed at reconciliation of economic and environmental aspects of the production process. A new mathematical model of material flows' cost introduced in generalized form, its differences from standard model are shown. In particular, given model takes into account production process' time parameters and can be used for analysis of systems with an arbitrary structure; it does, however, require significantly more input data, as calculations make use of momentary material flows' values and not accumulated values for a time period. With the help of new model cases are illustrated, in which application of standard method can provide incorrect information. Based on the model, three types of material resources efficiency indicators are formulated and a way of their application in optimal planning procedures is shown. Finally, advantages and drawbacks of the method in general are discussed, as well as prospects of its further development.
\end{abstract}

Keywords: management, material resources efficiency, material flows cost accounting.

\section{Introduction}

For industrial enterprises material resources are the place where significant amount of funds is concentrated, thus they have always been the subject to managerial activities. Today, however, the problem of efficient material resources management is particularly acute, as the political tensions and the global economic instability greatly increase price of decisions made [1]. In addition, in the second half of 20th century the idea of profit maximization was replaced by the concept of sustainable development, which led to new understanding of material resources efficiency [2]. Therefore, a need has arisen for the development of innovative, scientifically approved tools and methods that would allow integration of economical, environmental and social problems. Prominent examples of such tools are MFCA (Material Flow Cost Accounting) [3] и LCA (Life Cycle Analysis) [4], both included in the ISO 14000 standards family $[5,6]$ and used for strategic planning in large industrial enterprises as well as government bodies in several countries of Europe and Asia.

In Russian Federation transition to sustainable development officially began with the decrees of the President [7, 8]. As a result, a system of standards harmonized with the ISO 14000 was developed, outlining guidelines on implementation of the manufacturing processes. In particular, "Resource Saving" series is of interest, as related papers deal with material resources efficiency evaluation and improvement [9]. In the standard, an effective material resource management is described as following: "An activity to ensure timely and complete production cycle at the plant, in the organization of materials supply in accordance with the standards, technological rules and regulations. To design and implement industry-specific requirements for waste reduction, as well as procedure of waste management for each stage of technological cycle." Standards also provide an insight on potential ways to improve material resources efficiency, best available technologies and relevant methods of planning and control within different industries.

Material resources efficiency evaluation approach presented in this paper is based on MFCA - an inputloutput analysis method proposed in Germany in the 1980s. In the 2000s it was further developed and promoted in Japan by the efforts of the Ministry of Economy, Trade and Industry. Today there are many evidences of successful application of MFCA in different industries [10]. There is also a software product available, that provide means to create MFCA models and calculate their characteristics [11]. MFCA gives a view at the complete system of interactions between environment and the subject (depending on scope it can be separate department, an enterprise or a supply chain). Thus it enables managers to design and implement measures to improve material resources efficiency with regard to 


\section{Краткие сообщения}

systemic effect, rather than "end-of-pipe" solutions inherent to conventional practice [3]. However, a mathematical inconsistency was noticed during MFCA model analysis. In the article a new generalized model is proposed and along with it the inconsistency is illustrated.

\section{Terms and definitions}

An aggregate of production process can be viewed as a set of quantification centers (QC) linked by material flows. Quantification center can represent any part of production process where means to register amounts of incoming and outgoing materials exist. Material flow is the amount of material resources (raw materials or parts in processing) transported from one quantification center to another during selected time period. It is advised to select the scope of the model so that incoming and outgoing material flows would be as homogeneous as possible since it will affect relevance of calculations. Thus, a manufacturing system with $n$ quantification centers may be represented using the network model shown in Fig. 1:

The model shown in Fig. 1 is a weighted graph with $2 n+n(n-1)$ edges. Quantity centers with numbers 0 and $n+1$ are artificial and have special meaning. Material flows from QC 0 represent shipments from external providers, as well as wares taken from internal stocks. Material flows coming to QC $n+1$ represent shipments to external consumers and replenishment of internal stocks.

We denote amount of materials sent from QC $i$ to QC $j$ at time $t$ as $\mathrm{O}_{i j}(t)$. Amount of materials received $-\mathrm{I}_{i j}(t)$. If it takes $t_{i j}$ for materials to reach QC $j$ from QC $I$, then we can say that $\mathrm{O}_{i j}(t)=\mathrm{I}_{i j}\left(t+t_{i j}\right)=$ $=\mathrm{M}_{i j}(t)$, With this denotations we can represent a quantity center as it shown in Fig. 2:

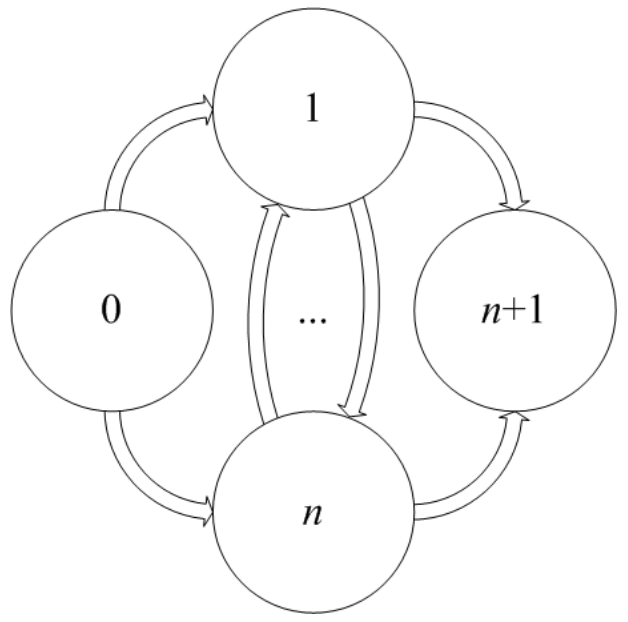

Fig. 1. Manufacturing system network model

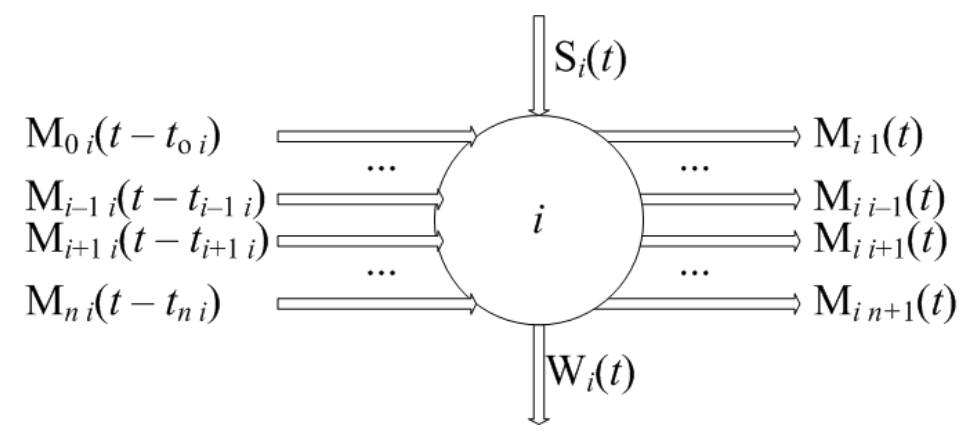

Fig. 2. Quantification center

In the Fig. $2 \mathrm{~S}_{i}(t)$ stands for system costs which consist of equipment amortization, salaries, energy costs and so on. $\mathrm{W}_{i}(t)$ - amount of generated waste, which is calculated with the help of material balance equations:

$$
\mathrm{W}_{i}(t)=\sum_{j=0}^{n} \mathrm{M}_{j i}\left(t-t_{j i}\right)-\sum_{j=1}^{n+1} \mathrm{M}_{i j}(t)
$$

Waste processing cost (per unit) at QC $i$ we will denote as $W p c_{i}$. System costs, waste processing costs and volumes (masses) of material flows are considered to be known values and make up inputs of the model.

Besides volume (mass), material flows also have value, or cost. We denote cost of material flow $\mathrm{M}_{i j}(t)$ as $\mathrm{Mc}_{i j}(t)$ and calculate it by following formulae:

$$
\mathrm{Mc}_{i j}(t)=\frac{\mathrm{M}_{i j}(t)}{\sum_{k=0}^{n} \mathrm{M}_{k i}\left(t-t_{k i}\right)}\left(\mathrm{S}_{i}(t)+\sum_{k=0}^{n} \mathrm{Mc}_{k i}\left(t-t_{k i}\right)+W p c_{i} \mathrm{~W}_{i}(t)\right) .
$$

Waste $\operatorname{cost} \mathrm{Wc}_{i}(t)$ is calculated in similar way: 


$$
\mathrm{Wc}_{i}(t)=\frac{\mathrm{W}_{i}(t)}{\sum_{k=0}^{n} \mathrm{M}_{k i}\left(t-t_{k i}\right)}\left(\mathrm{S}_{i}(t)+\sum_{k=0}^{n} \mathrm{Mc}_{k i}\left(t-t_{k i}\right)+W p c_{i} \mathrm{~W}_{i}(t)\right) .
$$

By dividing (3) by sum of (2) and applying (1), another expression for $\mathrm{Wc}_{i}(t)$ can be obtained:

$$
\mathrm{Wc}_{i}(t)=\frac{\sum_{j=0}^{n} \mathrm{M}_{j i}\left(t-t_{j i}\right)-\sum_{j=1}^{n+1} \mathrm{M}_{i j}(t)}{\sum_{j=1}^{n+1} \mathrm{M}_{i j}(t)} \sum_{j=1}^{n+1} \mathrm{Mc}_{i j}(t) .
$$

The first multiplier in (2) and (3) determines how value is distributed between outgoing material flows. In this particular case it is mass proportion, although any coefficients $D_{i j}$ (for outgoing flows) and $D w_{i}$ (for waste) can be used as long as condition $\sum_{j=1}^{n+1} D_{i j}+D w_{i}=1$ is satisfied. The condition is required to ensure integrity of the model by preserving amount of funds invested in production. The second multiplier in (2) and (3) represents accumulated in QC $i$ value that is made up from system costs, incoming flows costs and waste processing cost.

\section{Calculation of indicators}

Estimated waste costs can be used as-is to point out critical areas in manufacturing process. However, for comparative analysis and planning it would be more reasonable to calculate proportion of waste costs in total funds invested as such indicator is less sensitive to fluctuations in production rate. Then said indicator (denoted as $C$ ) for period of time between $t 0$ and $t 1$ can be calculated with following formulae:

$$
C=\frac{\sum_{i=1}^{n} \int_{t 0}^{t 1} \mathrm{Wc}_{i}(t) \mathrm{d} t}{\sum_{i=1}^{n} \int_{t 0}^{t 1}\left(\mathrm{Mc}_{0 i}\left(t-t_{0 i}\right)+\mathrm{S}_{i}(t)+W p c_{i} \mathrm{~W}_{i}(t)\right) \mathrm{d} t} .
$$

Unknown functions $\mathrm{W}_{i}(t)$ and $\mathrm{Wc}_{i}(t)$ can be found from equations (1) and (4) respectively. Functions $\mathrm{Mc}_{i j}(t)$ - from equations (2). For network models with no loops finding $\mathrm{Mc}_{i j}(t)$ is simple. In most general case, however, it is not a trivial task. It is also worth noting that coefficients

$$
\begin{aligned}
& D_{i}=\sum_{j=1}^{n+1} D_{i j}=\frac{\sum_{j=1}^{n+1} \mathrm{M}_{i j}(t)}{\sum_{j=0}^{n} \mathrm{M}_{j i}\left(t-t_{j i}\right)} ; \\
& D w_{i}=1-D_{i}=\frac{\sum_{j=0}^{n} \mathrm{M}_{j i}\left(t-t_{j i}\right)-\sum_{j=1}^{n+1} \mathrm{M}_{i j}(t)}{\sum_{j=0}^{n} \mathrm{M}_{j i}\left(t-t_{j i}\right)}
\end{aligned}
$$

show material consumption rate in QC $i$. This rate depends mostly on equipment condition and setup, in normal circumstances it does not change much with time [12]. Therefore the integral

$$
\int_{t 0}^{t 1} \mathrm{Wc}_{i}(t) \mathrm{d} t=\int_{t 0}^{t 1}\left(\frac{\sum_{j=0}^{n} \mathrm{M}_{j i}\left(t-t_{j i}\right)-\sum_{j=1}^{n+1} \mathrm{M}_{i j}(t)}{\sum_{j=1}^{n+1} \mathrm{M}_{i j}(t)} \sum_{j=1}^{n+1} \mathrm{Mc}_{i j}(t)\right) \mathrm{d} t
$$

can be slightly simplified:

$$
\int_{t 0}^{t 1} \mathrm{Wc}_{i}(t) \mathrm{d} t=\frac{1-D_{i}}{D_{i}} \sum_{j=1}^{n+1} \int_{t 0}^{t 1} \mathrm{Mc}_{i j}(t) \mathrm{d} t
$$

In MFCA total material flow cost must be calculated with following formulae: 


$$
\int_{t 0}^{t 1} \mathrm{Mc}_{i j}(t) \mathrm{d} t=\frac{\int_{t 0}^{t 1} \mathrm{M}_{i j}(t) \mathrm{d} t}{\sum_{k=0}^{n} \int_{t 0}^{t 1} \mathrm{M}_{k i}\left(t-t_{k i}\right) \mathrm{d} t} \int_{t 0}^{t 1}\left(\mathrm{~S}_{i}(t)+\sum_{k=0}^{n} \mathrm{Mc}_{k i}\left(t-t_{k i}\right)+W p c_{i} \mathrm{~W}_{i}(t)\right) \mathrm{d} t .
$$

However, plain integration of (2) gives slightly different expression:

$$
\int_{t 0}^{t 1} \mathrm{Mc}_{i j}(t) \mathrm{d} t=\int_{t 0}^{t 1} \frac{\mathrm{M}_{i j}(t)}{\sum_{k=0}^{n} \mathrm{M}_{k i}\left(t-t_{k i}\right)}\left(\mathrm{S}_{i}(t)+\sum_{k=0}^{n} \mathrm{Mc}_{k i}\left(t-t_{k i}\right)+W p c_{i} \mathrm{~W}_{i}(t)\right) \mathrm{d} t .
$$

This illustrates the inconsistency mentioned in the introduction. Expressions (6) and (7) are equal in one particular case when material flows volumes are constant or insignificantly change with time. Then we can denote $(t 1-t 0) \mathrm{M}_{i j}\left(t_{\mathrm{r}}\right)=M_{i j},(t 1-t 0) \mathrm{Mc}_{i j}\left(t_{\mathrm{r}}\right)=M c_{i j},(t 1-t 0) \mathrm{W}_{i j}\left(t_{\mathrm{r}}\right)=W_{i j},(t 1-t 0) \mathrm{Wc}_{i j}\left(t_{\mathrm{r}}\right)=W c_{i j}$, $\int_{t 0}^{t 1} S_{i}(t) \mathrm{d} t=S_{i}$, where $t 0 \leq t_{\mathrm{r}} \leq t 1$. With these denotations equation (2) takes the form:

$$
M c_{i j}=\frac{M_{i j}}{\sum_{k=0}^{n} M_{k i}}\left(S_{i}+\sum_{k=0}^{n} M c_{k i}+W p c_{i} W_{i}\right)
$$

Expressions (8) form a system of $n^{2}$ linear equations (by the number of edges with unknown values in the network model) with $n^{2}$ variables. This greatly simplifies calculations, but in most cases the assumption is contrary to real situation and may lead to distortion of the information received from the model. Another issue is related to analysis of looped manufacturing systems, where portion of generated waste is reused. In MFCA looping material flows do not add value to the QC they reach, so that the consequential calculation algorithm it employs can be completed in a one go. In return, overall value allocation is wrong. Actual degree of deviation between indicators is subject to separate research and requires collection and analysis of experimental data.

Usually quantification centers can be related to separate facilities within the enterprise. In this case three different types of efficiency indicators can be calculated: for an individual QC, for a group of QCs and, finally, for system in general. These indicators are of interest for managers of different levels and can be utilized for solving corresponding administrative tasks. To formally define the material resources efficiency indicator for a set group of QCs, we introduce following denotations: $m$ - number of groups in the system; $\omega_{p}$ - numbers of QCs that belong to the group $p ; \Omega$ - set of all QCs numbers. Obviously $\omega_{p}$ must not have any common elements, which means that $\bigcap_{p=1}^{m} \omega_{p}=\varnothing$. Then material resources efficiency $c_{p}$ within group $p$ for the time period between $t 0$ and $t 1$ can be defined in a way, similar to (5):

$$
c_{p}=\frac{\sum_{i \in \omega_{p}} \int_{t 0}^{t 1} \mathrm{Wc}_{i}(t) \mathrm{d} t}{\sum_{i \in \omega_{p}} \int_{t 0}^{t 1}\left(\sum_{j \in \Omega / \omega_{p}} \mathrm{Mc}_{j i}\left(t-t_{j i}\right)+\mathrm{S}_{i}(t)+W p c_{i} \mathrm{~W}_{i}(t)\right) \mathrm{d} t} .
$$

As mentioned before, indicators $c_{p}$ are used for comparative analysis of several facilities or different configurations of one facility. The analysis provides support to decision making in planning of equipment renovation, changes in product design and bill of materials. Another example of the indicators application is allocation of production rates between available facilities. Formally, this task can be viewed as linear programming problem, where objective function $Z=c_{1} x_{1}+c_{2} x_{2}+\ldots+c_{m} x_{m} \rightarrow$ min. Variables $x_{p}=\sum_{i \in \omega p} M_{i n+1}$ there represent amount of production to be produced at the facility $p$. Limitations for the problem are derived from facilities throughput, available stocks of materials, allowed amounts of waste and so on. 


\section{Prospects of further development}

Application of the proposed method to the planning process involves a number of difficulties related to instability of the calculated indicators: while indicators are less sensitive to changes in production rates, any alteration of facility logistics or equipment setup will change coefficients $D_{i j}$ and $D w_{i}$ and indicators $c_{p}$ along with them. Another problem is that fluctuations of system and material costs make it impossible to use efficiency indicators for long-term planning, as it invalidates value allocated between material flows. To alleviate this problem, however, it is possible to provide predicted costs to the model. Thus, integration of different managerial and economic tools aimed to improve capabilities of the method is the main development prospect.

Mathematical model shown in the article provides fine base for calculations automation. It also requires a lot of data that have to be collected and stored for multiple reuses. At the moment, there is only one software product on the market that enables MFCA [12]. Since it utilize standard cost calculation algorithm with inherited limitations, development of the new information system is an urgent task as well.

\section{Conclusion}

MFCA became a major tool for material resources efficiency evaluation as more and more civilized countries strive to achieve sustainable development. It enables managers to take in consideration both economical and ecological aspects of production process, to acknowledge cost allocation between stages of the technological cycle or facilities within the supply chain. MFCA implementation within a company helps to systemically reduce production costs and amounts of waste generated.

To enhance MFCA, a new generalized model was introduced in the article. The model takes into account reused materials during value allocation process. It is also shown, that the value of material flow accumulated during a time period should be calculated in a different way. However, there are a number of mathematical complications involved in the development of proper algorithm, which makes it a prospect for further research.

Another way to improve MFCA is outlined in the last section of the article. It lies in integration of MFCA with other analysis tools, such as mathematical programming and Markov chains, as well as adoption of the method to the long term planning [13].

\section{References}

1. Loginovskiy O.V. Upravlenie: teoriya i praktika [Management: Theory and Practice]. Moscow, Mashinostroenie Publ., 2011. vol.5. 1152 p.

2. Meadows, D.L. The Limits to Growth. New York, Universal Books Publ., 1972. 205 p.

3. Manual on Material Flow Cost Accounting: ISO 14051. Tokyo, Asian Productivity Organization Publ., 2014. 25 p.

4. Hans B., Robert D., Mark A.J.H. Handbook on Life Cycle Assessment. New York, Springer Publ., 2002. 684 p.

5. Environmental management - Material flow cost accounting - General framework: ISO 14051:2011. Available at: https://www.iso.org/obp/ui/\#iso:std:iso:14051:ed-1:v1:en (accessed 4 February 2016).

6. Environmental management - Life cycle assessment - Principles and framework: ISO 14040:2006. Available at: https://www.iso.org/obp/ui/\#iso:std:iso:14040:en. (accessed 4 February 2016).

7. O kontseptsii perekhoda Rossiyskoy Federatsii k ustoychivomu razvitiyu [On the concept of Russian Federation Transition to Sustainable Development]: decree of the President of the Russian Federation from 1 April 1996 № 440. Sobranie zakonodatel'stva Rossiyskoy Federatsii [Laws of the Russian Federation], 1996, no. 15.

8. O gosudarstvennoy strategii Rossiyskoy Federatsii po okhrane okruzhayushchey sredy i obespecheniyu ustoychivogo razvitiya [On the State Strategy of the Russian Federation on Environmental Protection and Sustainable Development]: decree of the President of the Russian Federation from 4 February 1994 № 236. Sobranie zakonodatel'stva Rossiyskoy Federatsii [Laws of the Russian Federation], 1994, no. 6.

9. Resursosberezhenie. Obshchie polozheniya [Resource Saving. General]: State Standard 521062003, effective since 1 August 2004. Moscow, Izdatel'stvo standartov Publ., 2004.

10. MFCA Case Studies. Ed.: K. Kokubo [et al.]. Tokyo, METI Publ., 2010. 93 p. 


\title{
Краткие сообщения
}

11. Schmidt A., Hache B., Herold F., Gotze U. Material Flow Cost Accounting with Umberto. Available at: http://www.qucosa.de/fileadmin/data/qucosa/documents/10906/2-05_Material_Flow_Cost_ Accounting_with_Umberto.pdf (accessed 4 February 2016)

12. Khaldin K.S. Modeli otsenki effektivnosti ispol'zovaniya resursov promyshlennogo predpriyatiya [Models for Evaluating the Material Resources Efficiency of an Industrial Enterprise]. Management in Social and Economic Systems, 2015, no. 3. pp. 129-134. (in Russ.)

13. Stefan S., Dimitar Z. Expanding Material Flow Cost Accounting. Framework, Review and Potentials. Available at: http://www.sciencedirect.com/science/article/pii/S0959652614008634 (accessed 4 February 2016).

Received 13 December 2015

\section{МЕТОД ОЦЕНКИ ЭФФЕКТИВНОСТИ ИСПОЛЬЗОВАНИЯ МАТЕРИАЛЬНЫХ РЕСУРСОВ ДЛЯ ПРОИЗВОДСТВЕННЫХ СИСТЕМ С ОБОБЩЕННОЙ СТРУКТУРОЙ}

\author{
К.С. Халдин \\ Южно-Уральский государственный университет, г. Челябинск
}

\begin{abstract}
Описывается новый способ измерения эффективности использования материальных ресурсов на промышленных предприятиях. Данный способ основывается на методике оценки стоимости материальных потоков и предполагает взаимоувязку экономических и экологических показателей производственного процесса. В общем виде приводится специальная математическая модель стоимости материальных потоков, демонстрируются ее отличия от стандартной модели. В частности, предложенная модель учитывает временные характеристики производственного процесса и может быть использована для анализа систем с произвольной структурой, однако требует значительно большего объема исходных данных, поскольку в расчетах используются значения объемов материальных потоков в отдельные моменты времени, а не накопленные значения за отчетный период. Также с помощью специальной модели проиллюстрированы случаи, в которых использование стандартной методики может привести к получению заведомо неверной информации. На основе предложенной математической модели сформулированы оценки трех видов и показан способ их применения в задачах оптимального планирования. Наконец, обсуждаются достоинства и недостатки метода в целом, а также перспективы его дальнейшего развития.

Ключевые слова: управление, эффективность, оценка материальных потоков.
\end{abstract}

\section{Лuтература}

1. Логиновский, О.В. Управление: теория и практика: в 5 m. - М.: Машиностроение-1, 2011. T. 5. $-1152 \mathrm{c}$.

2. Meadows, D.L. The Limits to Growth. - New York: Universe Books, 1972. - 205 p.

3. Manual on Material Flow Cost Accounting: ISO 14051. - Tokyo: Asian Productivity Organization, 2014. $-25 \mathrm{p}$.

4. Hans, B. Handbook on Life Cycle Assessment / B. Hans, D. Robert, A.J.H. Mark. - New York: Springer, 2002. $-684 \mathrm{p}$.

5. Environmental management - Life cycle assessment - Principles and framework: ISO 14040:2006. - https://www.iso.org/obp/ui/\#iso:std:iso:14051:ed-1:v1:en (дата обращения: 4 февраля 2016).

6. Environmental management - Material flow cost accounting - General framework: ISO 14051:2011. - https://www.iso.org/obp/ui/\#iso:std:iso:14040:en. (дата обращения: 4 февраля 2016). 
7. О конщепџии перехода Российской Федерачии к устойчивому развитию: указ Президента Российской Федерации от 1 апреля 1996 г. № 440 // Собрание законодательства Российской Федераиии. - 1996. - № 15.

8. О государственной стратегии Российской Федеращии по охране окружающей среды и обеспечению устойчивого развития: указ Президента Российской Федерачии от 4 февраля 1994 г. № 236 // Собрание законодательства Российской Федераиии. - 1994. - № 6.

9. ГОСТ Р 52106-2003. Ресурсосбережение. Общие положения. - Введ. 01.07.2004. - М.: Изд-во стандартов, 2003.

10. MFCA Case Studies / ed.: K. Kokubo [et al.]. - Tokyo: METI, 2010. - 93 p.

11. Schmidt, A. Material Flow Cost Accounting with Umberto / A. Schmidt, B. Hache, F. Herold, U. Gotze. - http://www.qucosa.de/fileadmin/data/qucosa/documents/10906/2-05_Material_Flow_Cost_ Accounting with Umberto.pdf (дата обращения: 4 февраля 2016).

12. Халдин, К.С. Модели оченки эффективности использования ресурсов промышленного предприятия // Сборник научных трудов «Управление в соииальных и экономических системах» / под ред. д.т.н., проф. О.В. Логиновского. - 2015. - № 3. - С. 129-134.

13. Stefan, S. Expanding Material Flow Cost Accounting. Framework, Review and Potentials / S. Stefan, Z. Dimitar // Journal of Cleaner Production. - http://www.sciencedirect.com/science/article/ pii/S0959652614008634 (дата обращения: 4 февраля 2016).

Халдин Константин Сергеевич, аспирант кафедры информационно-аналитического обеспечения управления в социальных и экономических системах, Южно-Уральский государственный университет, г. Челябинск; lar3811@yandex.ru.

Поступила в редакцию 13 декабря 20152.

\section{ОБРАЗЕЦ ЦИТИРОВАНИЯ}

Khaldin, K.S. Material Resources Efficiency Evaluation Method for Manufacturing Systems with Generalized Structure / K.S. Khaldin // Вестник ЮУрГУ. Серия «Компьютерные технологии, управление, радиоэлектроника». - 2016. - Т. 16, № 1. - С. 153-159. DOI: $10.14529 /$ ctcr 160114

\section{FOR CITATION}

Khaldin K.S. Material Resources Efficiency Evaluation Method for Manufacturing Systems with Generalized Structure. Bulletin of the South Ural State University. Ser. Computer Technologies, Automatic Control, Radio Electronics, 2015, vol. 16, no. 1, pp. 153-159. DOI: $10.14529 /$ ctcr 160114 